\title{
Builder of Enthusiasm: Shaping a New Profession for the Machine Age
}

CHOON CHOI

Seoul National University
A closer study of the profession of industrial design, as an antithetical practice to architecture, reveals more than what architecture is not; it brings to light some of the residual values in the architectural profession, and inert forces within it, responsible for the dilating disparity between architecture and society at large. By illuminating the historical context in which industrial design as a profession emerged in the post-war America against the backdrop of rapidly expanding middle class and unprecedented material abundance, architects can recalibrate the future trajectory of the profession in alignment with shifting economic contexts.

\section{INTRODUCTION}

During the post-war fifties in America, the disparity between architecture and technology was perceived with more acuity, and its cause was traced to the diffidence among architects to abandon some of their antiquated values that had defined their profession for centuries. Progressive critics called for a radical revision of the architectural values according to the ethos of new technology, and the urgency of professional re-alignment was dramatized by extreme forecasts, as the one pronounced by Reyner Banham: "It may well be that what we have hitherto understood as architecture, and what we are beginning to under-stand of technology are incompatible disciplines. The architect who proposes to run with technology knows now that he will be in fast company, and that, in order to keep up, he may have to...discard his whole cultural load, including the professional garments by which he is recognized as an architect." 1

Industrial designers, however, quickly stepped in and put on the new professional garment of the Machine Age, and architects remained trapped in the past. Since then, the rift between architecture and industrial design has continued to get wider, and a sense of mutual envy often turned into bitterness, and architects, in turn, raised the entry barrier to the profession, further diminishing the prospects for survival of their increasingly unpopular profession. Most vocal among the architects resentful of industrial design was R. Buckminster Fuller, who harboured a deep sense of mistrust and antagonism toward the profession of industrial design. Fuller denounced industrial design with his characteristic incoherence, as the "greatest betrayal of mass communication integrity in our era." The eleven titles that introduced him in his autobiographical Utopia or Oblivion indeed left out industrial designer. Instead, he was "comprehensive designer"

Industrial designers understood from the beginning how to work intimately in collaboration with capitalistic enterprises. One of the pioneers of industrial design, Harold Van Doren, offered a lucid description of his nascent profession in his Industrial Design: $A$ Practical Guide:

At his best, the designer is an animator, a builder of enthusiasm in others... He is creative without being crackbrained. He is practical without being timid. He knows how to work with others, meeting executives on an equal footing and still gaining confidence of the man of the bench. ${ }^{2}$

STYLING THE “NEW DEAL”: ORIGIN OF A PROFESSION

The job of an industrial designer is to interpret the function of useful things in terms of appeal to the eye; to endow them with beauty of form and color; above all to create in the consumer the desire to possess. $^{3}$

The emergence of industrial design as a profession can be traced back to the stock market crash of 1927. Recession followed, and corporations, to resolve the problem of over-production, realized that facelifting their products could induce increase in sales; over-production was conversely viewed as under-consumption. Corporations sought assistance from their advertising agencies, who in turn contacted artists. For the sake of convenience mostly, the artists from the fields closely related to advertising were recruited, such as poster art, typography, product illustration, and theatrical design.

That many of these first industrial designers came from theater is an ironic revelation. The birth of the profession of industrial design in America coincided with the tide of conversions of live theaters to movie theaters, resulting in wide-spread unemployment among theatrical designers. Looking for a new career, the set designers discovered industrial design, which seemed compatible with, or even identical to their experiences in theater: "Designing stage settings 
is an exacting art and valuable training for the fledgling industrial designer. In the theater, the final determining factor of success is audience approval, just as in the markets of trade the measure of success is customer approval of consumer goods." ${ }^{4}$ Even for set designers who had accomplished considerable fame in theater, the transition into industrial design was not forfeiture of their original trade but merely a shift in focus. Siegfried Giedion also recognized the intimate connection between these two fields when he wrote, "[industrial designer's] influence on the shaping of public taste is comparable only to that of the cinema." ${ }^{5}$ The victims of mechanization swiftly rebranded themselves as guardians of industrial production.

Industrial designers, as these artists were later called, were fully aware of their responsibility which rested on financial success: "Stripped of hocus-pocus, the goal of design is sales-at a profit." Statistics gave the new profession a degree of respect and authority. After Raymond Loewy re-styled the cabinet of a radio, the sales increased seven-fold. Similarly dramatic successes by other pioneer designers con-vinced corporations that concentrating on the appearance of their products rather than performance could provide immediate results. Corporate mentality on the part of the designer qualified him to serve the corporate clients. Eventually, corporations dispelled all doubts as to the crucial role of the industrial designer in the process of mass production. Industrial designers established their status as the artists of the Machine Age. ${ }^{7}$

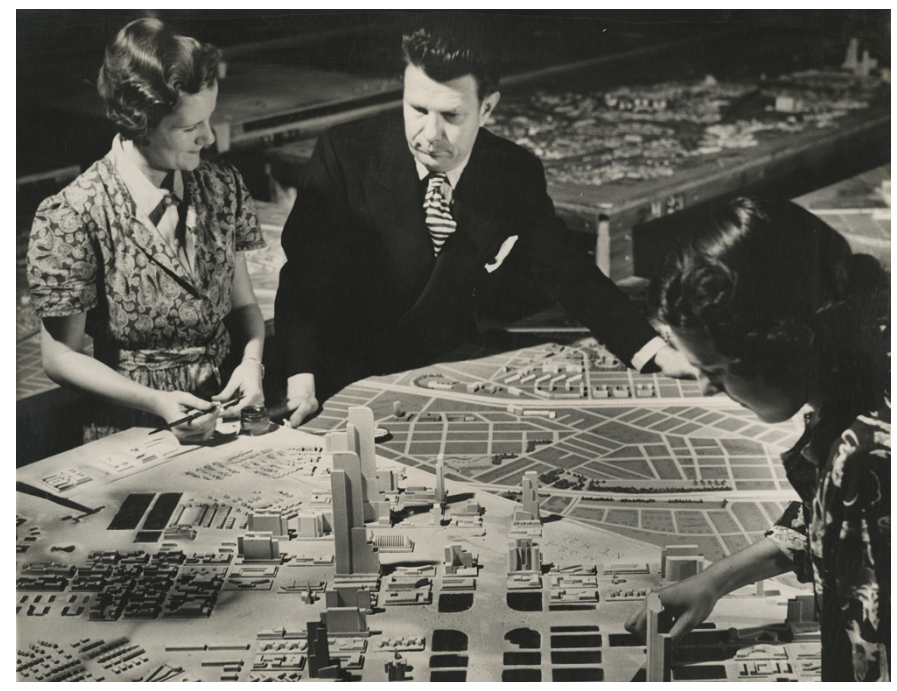

Figure 1 Geddes with Futurama diorama, photograph by Richard Garrison, ca. 1939. (Image courtesy of the Edith Lutyens and Norman Bel Geddes Foundation)

In 1927, the first industrial designer's office in America was established by Norman Bel Geddes. Already successful as poster artist and theatrical designer, Geddes decisively shifted his career from theatre to industrial design, reasoning that it was "more vitally akin to life today than the theatre." The commission which facilitated the organization of Geddes' office was given by Standard Gas Equipment Corporation, for redesigning their gas stoves. When Standard Gas Equipment Corporation offered Geddes $\$ 1,500$ to produce rough sketches for improving their gas stoves, he demurred, requesting instead $\$ 25,000$ for developing a new design in depth. His request was granted, and the first step of the design process was an extensive study of the current market for gas stoves, and a consumer survey of 1,200 housewives. This first phase revealed that ease of cleaning should be the main consideration in the new design. Competitors' models were then analysed, and Geddes' team recognized that a satisfactory design would need to fulfil practical, aesthetic, and psychological requirements, in addition to being easily manufactured and transported. The result incorporated an encompassing shell, with a skirt that extended to the floor, with top panels for covering the burners and controls when not in use. This continuous shell from top to bottom was given, for "psychological appeal," a finish of white, the most "sanitary color." Geddes' accomplishment was hailed by press as a "complete New Deal for the forgotten kitchen."

Geddes' design process established the standard to which subsequent designers adhered. In his book Horizons (1932), which, as one of the first books on industrial design, exerted great influence on defining a set of values for the new profession, both ethically and stylistically, Geddes laid out a step-by-step "sound design procedure":

1. Determine specific design objectives: the intended function to be served, the way it is made, sold, and serviced.

2. Visit the client's factory and determine the ca-pacity and limitations of the machines and the workers.

3. Research the competition, surveying the consum-ers' attitudes, and test the competitive product.

4. Consider the opinion of salesmen, engineers, advertisers, and other specialist. ${ }^{8}$

This procedure was followed faithfully, and served as the industry standard; it was highly specific, and deliberately practical, to counter the stereotypical image of an artist. Its elaborate and laborious requirements distinguished industrial designers from mere "commercial artists," who lacked the necessary support staff to carry out such extensive research, survey and testing. To gain a full trust from his corporate partners, Geddes fully understood that he had to rely on a collaborative process involving many different talents. Norman Bel Geddes worked with associates from diverse backgrounds and individual specialities, reflecting his belief that "specialized routine results in the formation of correct working habits, reduces errors to a minimum, establishes a standard method of work common to everyone in the office, lessens the strain on individuals, is more expeditious than optional methods, and frees higher-salaried persons from detail that can be done by lower-salaried em-ployees." 9 This form of partnership not only facilitated a more efficient production method, but also attempted to raise human productivity to a level commensurate to that of a machine, thereby avoiding any waste of industrial capacity: "A partnership it must always be, sincere and whole-hearted.... Good design, like most products of this machine age, is the result of a group activity....In no other way, except by this union of diverse talents, can we get from our machines the fair and beneficent world they are quite capable of building."10 


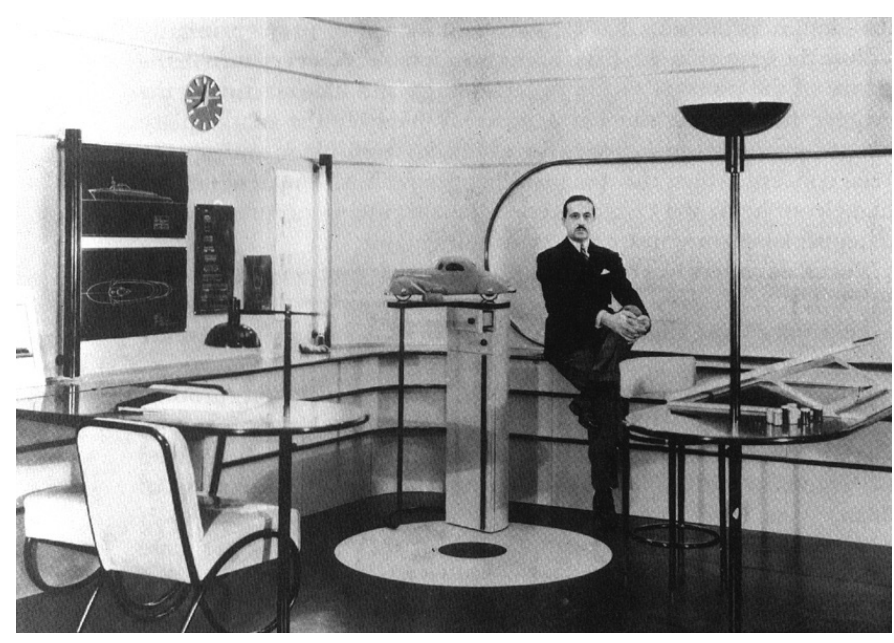

Figure 3. Raymond Loewy, "A Model Industrial Designer's Office and Studio," Contemporary American Arts Exposition (Image courtesy of the Raymond T.

\section{RAYMOND LOEWY: AESTHETICS OF A SALES CURVE}

From its conception, the industrial design as a profession was intimately tied to the consumer markets. Working with giant corporations, the first industrial designers earned respect based on statistics that showed a dramatic increase in sales after the implementation of their designs. It was crucial for the first industrial designers, whose clients were primarily corporate manufacturers looking for greater profits, to establish their public image firmly grounded on their ability to boost profits. As lucidly articulated by Raymond Loewy, "To an American designer, a conception of aesthetics consists of a beautiful sales curve, shooting upward."11 The industrial designer serves as a liaison between corporations and consumers. Moreover, they go beyond merely parroting the consumer's demands, and actively shape and guide the evolution of consumer taste. The first industrial designers, therefore, sought to perpetuate a public image of their profession as the epitome of good taste, and the connoisseur of the markets.

Flamboyant and French-born, Raymond Loewy most visibly adapted this image: "In essence, he looked like a designer," remarked a friend, recalling Loewy's frequent summer drives to Long Island in his "biggest white convertible [with] the most beautiful blonds." ${ }^{12}$ But in the famous photograph "A Model Industrial Designer's Office and Studio," Loewy projected a different image. Expressionless and sombre, Loewy in his dark business suit is the lonely figure in a compact, futuristic space. Poised behind his drafting table, the heroic designer probingly gazes back at the camera. His office is rendered with the severest of lines, and stripped of decoration, fluidity of the curving white surface accentuated only by horizontal chrome bands. The cornerless, washable walls are made of ivory Formica, the floor covered with blue linoleum, and the excessively bright indirect lighting, supplemented by spotlights, simulate a sterilized atmosphere of a medical clinic. Loewy aptly explained, "[industrial designer's office] is really a clinica place where products are exam-ined, studied, and diagnosed."13

Paradoxically, the photographed office was merely a stage set, "a model industrial designer's office and studio," installed in the
Contemporary American Arts Exposition of 1934 at the Metropolitan Museum of Art, New York. It was conceived by Raymond Loewy to portray to the viewing public an image of the ideal industrial designer's office, one that "imbued the designer with the public glamour of a scientist of technician while satisfying expectations of aesthetes." In reality, a typical industrial designer's office was crowded with the staff of draftsmen, model makers, accountants, and researchers. The collaborative nature of industrial design was fully embraced by Loewy himself, whose understanding of the "modern designer" was "a free-lancer and a consultant with his or her own studio staffed with assistants." This need to maintain a dual identity was vital to the ultimate success of the designer, since a carefully manipulated aura of an artistic genius with supreme taste provided an effective selling point.

Loewy's intervention ranged from subtle adjustment (changing the Lucky Strike package from green to white) to sensuous overhaul (Coca-Cola bottle), and helped build the branding images of many corporations, including Exxon, Shell, and US Postal Service, whose logos he created. His most ambitious graphic identity project was perhaps the Air Force One for J.F. Kennedy. He happened by chance to see the president's plane fly over his Palm Springs home, and told his friend who was a high-ranking general that he thought the plane looked "rather gaudy" and "terrible" and offered to help at no charge. His timeless design for Air Force One is still in use today.

\section{HENRY DREYFUS: DESIGNING FOR THE MASS MIND}

Q: What is the diving line between industrial design and architecture?

A: The industrial designer utilizes his study of the mass mind and the mass market and his experience in merchandizing generally...If he can produce a back-ground that invites customers to stop and shop and buy, he has given the building meaning. ${ }^{14}$

An outline of Dreyfuss' biography typifies the fortuitous manner in which the first industrial designers entered the new profession. After graduating from Ethical Culture Arts High School, Dreyfuss enrolled in a stage-design class taught by Norman Bel Geddes, whose career as a theatrical designer was then at its pinnacle. Dreyfuss worked as Geddes' assistant for two years, before Joseph Plunkett hired him to design sets for variety shows at the Strand Theater. In 1927, he found himself unemployed, as most of the variety theaters were being converted to movie houses. Looking for work, he travelled to Europe, only to be lured back to New York by an offer from Oswald Knauth, the vice-president of the Macy's Department Store, to become the new in-store stylist with a five-figure salary. His job description included surveying the products sold at the store, and making suggestions for improvements to the manufacturers. If the manufacturers did not comply, their products would no longer be sold through Macy's. After observing the store for two days, Dreyfuss surprised Oswald Knauth by turning down his offer. The reason was deeply rooted in his design philosophy: "An honest job of design should flow from the inside out, not from the outside in." He believed that the superficial method of prescribing stylistic changes from the store would produce disastrous results, since "a stylist should work with a manufacturer at the inception of a product in order to gain complete 
understanding." Another reason was that Dreyfuss feared such position would bind him with one organization, and prevent him from working as an independent designer in a field which he began to realize promised greater opportunities. Immediately, he opened his own office in 1928, and began designing small household items.

His unassuming philosophy concentrated on the user, and avoided preconceived styles, opting instead to focus on "human engineering." Fundamental themes of Dreyfuss' successful career were basically outlined in the creed that introduced his manifesto Designing for People:

We bear in mind that the object we are working on is going to be ridden on, sat upon, looked at, talked into, activated, operated, or in some other way used by people. If the point of contact between the product and the people becomes a point of frictions, then the industrial designer has failed. On the other hand, if people are made safer, more efficient, more comfort-able-or just plain happier, by contact with the prod-uct, then the designer has succeeded. ${ }^{15}$

This understated and practical attitude garnered respect from both within and outside his profession. Norman Bel Geddes, who was very critical of Loewy or Teague, found no faults in Dreyfuss: "I think he's honest, straight from the shoulder. There's nothing phony about him. He's square-just a good human being." Even Buckminster Fuller, whose disapproval of industrial design as the "greatest betrayal" as quoted earlier, praised Dreyfuss as a "leader in design revolution capable of bringing the human race to an utterly new omnisuccessful relationship to universe." 16

The willingness to forfeit immediate profit for more far-sighted goals became a pattern in Dreyfuss' career, as he repeatedly declined offers which he felt jeopardized his reputation as a dependable and responsible professional. In 1929, Bell Telephone Laboratories contacted ten designers and offered them 1,000 dollars each to produce sketches for an ideal telephone. Dreyfuss promptly declined to participate; such project, he replied, would be fruitless without close collaboration with company engineers. A year later, realizing how impractical were the designs pro-duced by those "commercial artists," Bell asked Dreyfuss to become the design consultant on the new desk phone project. Dreyfuss began working on the project in 1930, and it was seven years later in 1937 that the result was introduced. This model remained as the standard telephone until 1950, when it was replaced by another Dreyfuss design. Having found their niche, industrial designers distinguished themselves from architects by emphasizing their sensitivity to the masses and their business acumen.

\section{JOE AND JOSEPHINE: A DEDUCTIVE APPROACH TO HUMAN COMFORT}

The industrial design firm of Henry Dreyfuss reflects the over-riding interest of the man whose name it bears-an interest in people. The firm applies a five-point yardstick to the products it designs. The first of these is convenience of use, including utility and safety, and the second is ease of maintenance. Both of these factors relate directly to people and the other three, cost, sales, and appearance relate indirectly. It was because of this interest in people that the Dreyfuss office began about 30 years ago, to develop the figures of Joe and Josephine which now provide all the essential measurements of the male and female figure of the genus home sapiens. ${ }^{17}$

Joe and Josephine are the "percentile anthropometrical partners." They represent the mean 50 percentile of the statistical data compiled by Dreyfuss. In contrast to Le Corbusier's Le Modulor, which was a universally applicable proportioning system, standardized and subdivided according to mathematical logic, Dreyfuss' Joe and Josephine were based purely on statistics alone-a deductive approach to designing for human comfort. Joe and Josephine did not represent ideal proportions; they simply conformed to the patterns of the masses, therefore subject to adjustments and revisions as required by statistical updates.

Moreover, Dreyfuss' percentile partners included three variants: Ectomorph represented the 2.5-percentile small men; Mesomorph, the 50-percentile medium men; and Endomorph, the 97.5-percentile large men. The same logic was applied to Josephine and their children. This system left out the extreme 2.5 percentile groups on both ends, since "[Drey-fuss'] experience-plus the experience of human factors researchers who have gone into the subject more deeplyhas convinced us that these three human figures are enough for the designer's purposes." Still, this 95-percentile coverage was more comprehensive than the normal engineering data, which skipped the first and the last five percentile groups. ${ }^{18}$

Henry Dreyfuss' obsessive effort to chart all as-pects of potential users, as epitomized in the percentile anthropometric partners, demonstrated his commitment to "designing for people." He repeatedly argued for designing the machines to fit people, in-stead of squeezing people into machines. In this respect, Dreyfuss held steadfastly to Siegfried Giedion's exhortation: "To control mechanization

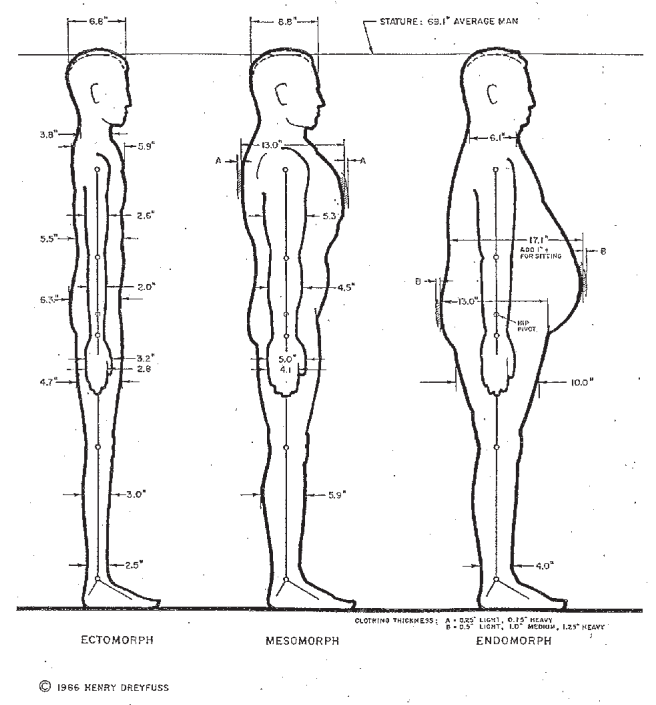

Figure 3. Henry Dreyfuss "Three Basic Human Body Types," (Source: The Measure of Man: Human Factors in Design) 
demands an unprecedented superiority over the instruments of production. It requires that everything be subordinated to human needs."

Dreyfuss' deductive approach to design also included thorough research into manufacturing process and market demands. When he was asked to design a low-cost house for mass production by Consolidated Vaultee, who was an airplane manufacturer hoping to enter the post-war housing market, Dreyfuss again illustrated a design approach that was drastically different from that of architects. Contrary to Le Corbusier's "Machine for Living", Dreyfuss' proposal for a prefabricated house adapted a strikingly familiar aesthetic. Using existing skills and facilities, to avoid elaborate retooling in the change-over from airplanes to houses, Dreyfuss based his design on his knowledge of consumer demands, his understanding of housing market, research into manufacturing techniques, and his grasp of costs. Treating the problem of pre-fabricated house as another type of assembly-line operation, Dreyfuss came up with the most efficient house that could be manufactured at the existing factory, without looking too different from everyday middle-class homes that the home buyers were looking for.

\section{CONCLUSION: LEARNING FROM INDUSTRIAL DESIGN}

A recurrent theme in the design methods of the first industrial designers was their emphasis on the concept of the average. In designing for mass production, the client is no longer specific or singular, but an unknown group of consumers. While the corporate sponsors may finance the design process, they are not the users of the products. Consequently, in order to make a profit, the de-signed product must appeal to the average taste. The concept of average is crucial in that it signifies the neutral middle ground, satisfying many while offending only few. The designer must clearly understand the needs of the audience, both practical and vain, rather than imposing one's own ideals. The first American industrial designers completely internalized these requirements, and actually made a sweet lemon out of the debased authority of a corporate designer by glorifying their democratic orientation. As Harold Van Doren summarized, "a designer should choose the middle course. Without underestimating

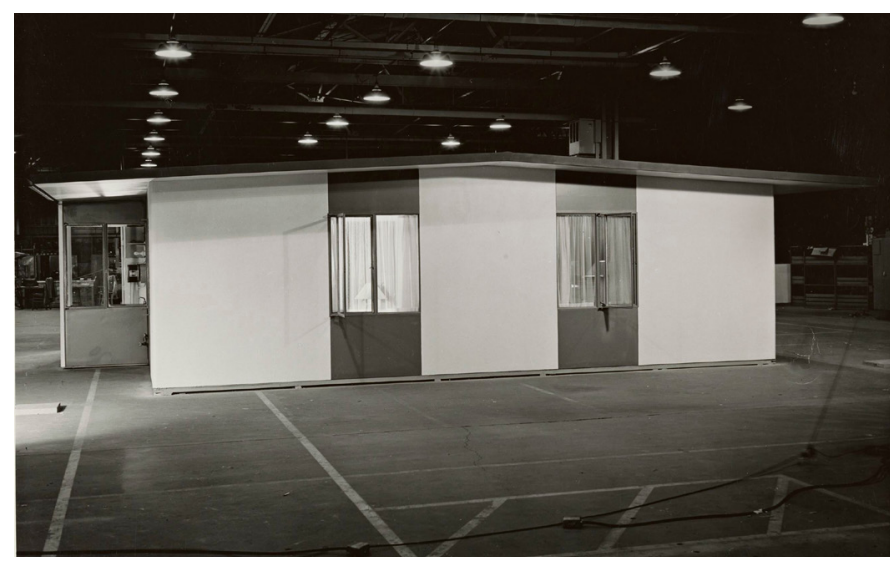

Figure 4. Henry Dreyfuss "Consolidated Vultee Prefabricated House, 1947" (Image courtesy of the Getty Archive) the taste of the public, he should provide the very best it will absorb, and not one bit more." 19

The other theme was the deductive approach to design, heavily dependent on research. Without imposing a predetermined ideal, the first generation of industrial designers tried to shape their proposals to appeal to the greatest number of consumers based on survey data. They avoided personal aesthetic agenda, but delivered highly flexible solutions that could be repeatedly revised and updated. Industrial designers first gained legitimacy from statistics that showed dramatic increases in sales after the implementation of their designs, and they regarded the statistical data also as a point of departure for their designs. Both altruistic and practical, this em-phasis on statistics also helped restrain the designer's egocentric control over the design process. Instead of posing as prophets of the future, the industrial designers tried to learn from the masses.

The last lesson from the pioneers of industrial design was to embrace collaborative teamwork as a vital condition for every creative process. This emphasis on collective intelligence led to democratization of the design process without a lonely genius dominating the scene. Working with a large group of highly qualified experts also created an added aura to the nascent industrial design practices by setting them apart from mere commercial artists. Designer as a director, or a manager of a team of diverse group of people also perpetuated the image of an industrial designer as a corporate partner who understood how large industrial companies were organized and run.

\section{ENDNOTES}

1. Reyner Banham, Theory and Design in the First Machine Age, New York: Praeger, 1960, pp. 329-330

2. Harold Van Doren, Industrial Design: A Practical Guide, New York: McGraw-Hill, 1940, p. 26

3. Ibid. p. XVII

4. Henry Dreyfuss, Desiging for People, rev. ed. 1967, reprinted 1974. New York: Viking Compass, p. 49

5. Siegfried Giedion, Mechanization Takes Command: A Contri-bution to Anonymous History, 1948. New York: Norton, p. 610

6. Ibid. p.3

7. Donald J. Bush, The Streamlined Decade, New York: George Braziller, 1975, pp. 16-18

8. Norman Bel Geddes, Horizons: In Industrial Design, Boston: Little, Brown, and Company, 1932.

9. Jeffrey L. Miekle, Twentieth Century Limited, p. 86

10. Walter Dorwin Teague, Design This Day: The Technique of Order in the Machine Age, New York: Harcourt, Brace and Company, 1940, p. 93-94

11. Raymond Loewy, quoted by Jeffrey L. Miekle, Twentieth Cen-tury Limited: Industrial Design in America, 1925-1939, p. 134

12. Jeffrey L. Miekle, Twentieth Century Limited, p.60

13 Ibid. p. 84

14 Henry Dreyfuss, Designing for People, rev. ed. 1967, reprinted, New York: Viking Compass, 1974, p. 217

15 Henry Dreyfuss, from the foreword to the Measure of Man: Human Factors in Design, New York: Whitney, 1959

16 Buckminster Fuller's foreword to Henry Dreyfuss, Designing for People, rev. ed. 1967, reprinted, New York: Viking Compass, 1974

17 Henry Dreyfuss, Measure of Man: Human Factors in Design, 1967, on the back cover.

18 Henry Dreyfuss, Measure of Man: Human Factors in Design, 1967, charts A1, A2, B1, B2, C, S1,

19. Harold Van Doren, Industrial Design: A Practical Guide in America, 1925-1939, New York: McGraw-Hill, p. 55 